\title{
Endothelin production by bovine oviduct epithelial cells
}

\author{
M. Rosselli, B. Imthurn, E. Macas and P. J. Keller \\ Department of Obstetrics and Gynecology. Clinic of Endocrinology, University Hospital, Zurich, \\ Switzerland
}

\begin{abstract}
The production of immunoreactive-endothelin by bovine oviduct epithelial cells in culture was studied. The minimum amount of endothelin detected in the supernatant of cultured bovine oviduct epithelial cells after $6 \mathrm{~h}$ of incubation was $97.3 \pm 10 \mathrm{pg}$ endothelin $\mathrm{mg}^{-1}$ protein and the amounts increased significantly $(P<0.01)$ with time of incubation. Pretreatment of bovine oviduct epithelial cells with the calcium ionophore A23187 increased the production of endothelin $(P<0.05)$. These results provide the first evidence that bovine oviduct epithelial cells produce endothelin and, therefore, may be locally involved in the muscular oviduct wall contractility and play an important role in the transport of gametes and embryos.
\end{abstract}

\section{Introduction}

The endothelins are a family of peptides, present as three isoforms (ET-1,2,3) and encoded by three distinct endothelinrelated genes. The active endothelins are 21 amino acid peptides cleaved from a 38-39 amino acid precursor (big ET) by an 'endothelin-converting-enzyme' (Inoue et al., 1989). Endothelin was first described as a vasoconstrictor substance derived from vascular endothelial cells. However, it is now known to be produced in many tissues and different types of cell (Yanagisawa et al., 1988; Kenigsberg et al., 1992). Furthermore, within the reproductive system the endometrial stromal and glandular epithelial cells produce endothelin (Economos et al., 1992). Large amounts of endothelin are also present in human seminal fluid (Casey et al., 1992). Endothelin exhibits a potent long-lasting vasoconstrictor/pressor activity and a wide spectrum of actions on a variety of non-vascular tissues including uterine smooth muscle (Kozuka et al., 1989). Furthermore, it possesses mitogenic properties (Komuro et al., 1988). Although the presence of endothelin in the reproductive system is well established, its role and regulation within the reproductive system have not been elucidated.

The oviduct provides the optimal environment for the transport of gametes, for the fertilization process, and for the development of early embryos (Sayegh et al., 1991).

Although the oviduct is under endocrine control, locally produced factors play a decisive role in regulation of oviduct function and therefore in the regulation of oviduct wall tone (contractility and relaxation), as well as in the ciliary motion of the oviduct epithelial cells (Yeko and Handler, 1991).

In the present study we provide the first evidence that immunoreactive endothelin is produced by cultured bovine oviduct epithelial cells. We hypothesize that endothelin is produced by the oviduct epithelial cells and could act as a paracrine factor exerting an effect on the underlying smooth muscle cells and hence, may be involved in the rhythmic

Revised manuscript received 26 May 1993 contraction of the oviduct. Alternatively, endothelin could play an important role in the transport of gametes and embryos.

\section{Materials and Methods}

\section{Isolation and culture of bovine oviduct epithelial cells}

Bovine oviduct epithelial cells were prepared by a modification of the method of Bongso et al. (1989). Briefly, oviducts were obtained from young nonpregnant cyclic cows killed at the local abattoir. Oviducts were placed immediately in ice-cold Hank's balanced salt solution (HBSS) containing $100 \mu \mathrm{g}$ streptomycin $\mathrm{ml}^{-1}, 100 \mathrm{iu}$ penicillin $\mathrm{ml}^{-1} ; 0.025 \mu \mathrm{g}$ amphotericin B ml ${ }^{-1}$ (all purchased from Gibco, Life Technologies Inc., Grand Island, NY). Oviducts were cleaned of the surrounding tissue and repeatedly washed with HBSS. The lumen of the oviduct was then gently superfused with $10 \mathrm{ml}$ of HBSS and the epithelial cells mechanically dislodged from the oviduct by rapidly flushing the oviduct three times with $20 \mathrm{ml}$ calcium- and magnesium-free HBSS. Epithelial cell layers were dislodged easily and were present in the form of sheets. Isolated cells were then suspended in HBSS and washed twice by centrifuging at $300 \mathrm{~g}$ for $10 \mathrm{~min}$. The final cell pellet was suspended in $4 \mathrm{ml} \mathrm{HBSS}$ and then layered over $5 \mathrm{ml}$ Percoll ( $1.07 \mathrm{~g} \mathrm{HBSS} \mathrm{ml}^{-1}$ ) and centrifuged for $20 \mathrm{~min}$ at $1000 \mathrm{~g}$. The cells present at the interface were then collected and washed twice with HBSS. The cells were suspended in complete media (Ham's-F10 culture media, $100 \mu \mathrm{g}$ streptomycin $\mathrm{ml}^{-1}, 100 \mathrm{iu}$ penicillin $\mathrm{ml}^{-1} ; 0.025 \mu \mathrm{g}$ amphotericin $\mathrm{B} \mathrm{ml}^{-1}$ (Gibco).

\section{Culture of bovine oviduct epithelial cells}

Freshly isolated bovine oviduct epithelial cells were suspended in complete medium containing $5 \%$ fetal calf serum (FCS; Flow Laboratory Inc., Irvine), plated in 6-well culture dishes and incubated overnight at $37^{\circ} \mathrm{C}, 5 \% \mathrm{CO}_{2}: 95 \%$ air and $98 \%$ humidity. After incubation overnight, the unattached cell Downloaded from Bioscientifica.com at $04 / 26 / 2023$ 01:22:49PM 
aggregates still in suspension were collected, washed twice with HBSS and trypsinized (0.05\% trypsin-EDTA; Gibco) until single cells were observed. Bovine oviduct epithelial cells were washed with complete culture medium containing $10 \%$ FCS and then plated and cultured in Ham's-F10, containing 5\% FCS under standard tissue culture conditions. Confluent bovine oviduct epithelial cells were trypsinized and cells in first passage used to evaluate endothelin synthesis. Bovine oviduct epithelial cells were plated at a density of $3 \times 10^{4}$ cells $\mathrm{ml}^{-1}$ in 24-well culture dishes and allowed to grow to subconfluency in the presence of Ham's-F10 medium, containing 5\% FCS and standard culture conditions. At subconfluency the bovine oviduct epithelial cells were washed twice with serum-free Ham's-F10 medium and then incubated for 6, 24 and $48 \mathrm{~h}$ in the presence of $1 \mathrm{ml}$ serum-free Ham's-F10 medium. Each experiment was conducted in duplicate and repeated three times using three different cultures of bovine oviduct epithelial cells. In studies conducted in parallel, cultured bovine oviduct epithelial cells were treated under identical conditions with

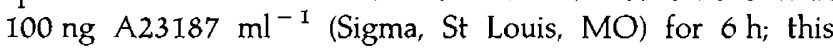
experiment was repeated five times with five different cell preparations. The supernatants were collected separately and centrifuged at $300 \mathrm{~g}$ for $10 \mathrm{~min}$, and the final supernatants, free of cell debris, were stored at $-20^{\circ} \mathrm{C}$ until assayed for endothelin. Total protein content of cells was assayed by the method of Lowry et al. (1951).

\section{Characterization of bovine oviduct epithelial cells}

Cell viability was tested in control and in treated wells with trypan-blue staining (Jacob and Pastan, 1979). The purity of the cell preparation was evaluated by reacting the cultured cells with monoclonal antibodies to cytokeratin; anti-CytokeratinCKI (Moll et al., 1982) (Dako Corporation, Carpinteria, CA) and immunostaining with peroxidase antiperoxidase (Dako). Cell nuclei were localized by Harris-haematoxylin (Merck, Darmstadt).

\section{Endothelin radioimmunoassays}

Endothelin was measured in $100 \mu \mathrm{l}$ aliquots, using a radioimmunoassay kit (ET $1,2\left({ }^{125} \mathrm{I}\right)$ assay system, RPA 545) purchased from Amersham (Amersham International, Amersham). This assay system is specifically immunoreactive to ET-I, ET-2 and big ET-1. The percentage of crossreactivity was $100 \%$ for synthetic ET-1 and ET-2, and $69 \%$ for porcine big ET-1. The crossreactivity observed for ET-3 was $<0.001 \%$ (Davenport et al., 1990). The sensitivity of the assay was within the range of $0.25-32.0 \mathrm{fmol}$ per tube $(0.623-79 \mathrm{pg}$ per tube). The inter- and intra-assay coefficients of variation were $5.9 \pm 1.6 \%$ and $5.3 \pm 1.06 \%$, respectively. To confirm that we were specifically measuring endothelin in the conditioned media, we estimated endothelin in three different aliquots $(50-400 \mu \mathrm{l})$ of the sample taken at $48 \mathrm{~h}$. Briefly, aliquots $(50$, $100,200,400 \mu \mathrm{l})$ of the supernatants collected from bovine oviduct epithelial cells cultured for $48 \mathrm{~h}$ were taken and the difference in sample volume normalized by adding blank culture media. The amount of endothelin was then estimated by radioimmunoassay and using a standard curve, which was run under identical conditions, i.e. made in the same blank media and adjusted for sample volume $(400 \mu \mathrm{l})$. To confirm that there was parallelism in the amount of endothelin measured in different aliquots, similar measurements were made in different aliquots of standard solution of endothelin $30 \mathrm{pg} \mathrm{ml}^{-1}$; prepared to match the concentrations present in the experimental sample taken at $48 \mathrm{~h}$. Linear regression analysis was then used to assess the relationships between the aliquots taken and the amounts of endothelin present. The slope values as well as the ratios between the endothelin concentrations of the experimental and standard solutions were compared to evaluate parallelism. The immunoreactive material detected in this radioimmunoassay is referred to as endothelin.

\section{Statistical analysis}

Results are expressed as means \pm SEM. Linear regression analysis and comparisons of the slopes were used to evaluate parallelism. Data were analysed using Student's $t$ test, and a $P$ value of $<0.05$ was considered statistically significant.

\section{Results}

\section{Culture of bovine oviduct epithelial cells}

Freshly isolated bovine oviduct epithelial cells appeared as sheets of cells with rapid movements due to the presence of cilia on the epithelial cells. After attachment to the culture surface, the cilia could not be observed on the bovine oviduct epithelial cells as detected by an inverted microscope. The primary cultures reached subconfluency in approximately 6-7 days, when plated at a density of $3 \times 10^{4}$ cells ml ${ }^{-1}$. The cells in culture showed characteristic epithelial morphology (Fig. Ia). Approximately $94 \%$ of the cells stained positively for anticytokeratin (CK1) antibodies (Fig. Ib).

\section{Endothelin production by bovine oviduct epithelial cells}

Significant amounts of immunoreactive endothelin were found in the supernatant of the bovine oviduct epithelial cells as detected by radioimmunoassay. The concentration of endothelin in the conditioned media of bovine oviduct epithelial cells in the first passage was at the minimum detectable level after $6 \mathrm{~h}$ in culture and increased significantly $(P<0.01)$ after $48 \mathrm{~h}$ in culture (Fig. 2). Furthermore, there was a linear or parallel increase in endothelin concentration, when estimated in $50,100,200,400 \mu \mathrm{l}$ aliquots of the sample taken at $48 \mathrm{~h}-$ $1.26 \pm 0.001 ; 2.78 \pm 0.005 ; 6.31 \pm 0.06 ; 12.92 \pm 0.0004$ pg per tube, respectively. The values represent the mean \pm SEM from a representative set of experiments conducted in triplicate and similar results were observed in three independent experiments. In addition, endothelin estimated in different aliquots $(50-$ $400 \mu$ l) of a standard endothelin solution showed a similar profile (data not shown). The slopes of the curves obtained from these assays were not significantly different from one another $(P>0.05)$, suggesting that there was parallelism, which further confirms the validity of the assay. Bovine oviduct epithelial cells incubated for $6 \mathrm{~h}$ in the presence of A23187 increased endothelin production from $97.3 \pm 10$ to $151 \pm$ Downloaded from Bioscientifica.com at 04/26/2023 01:22:49PM 

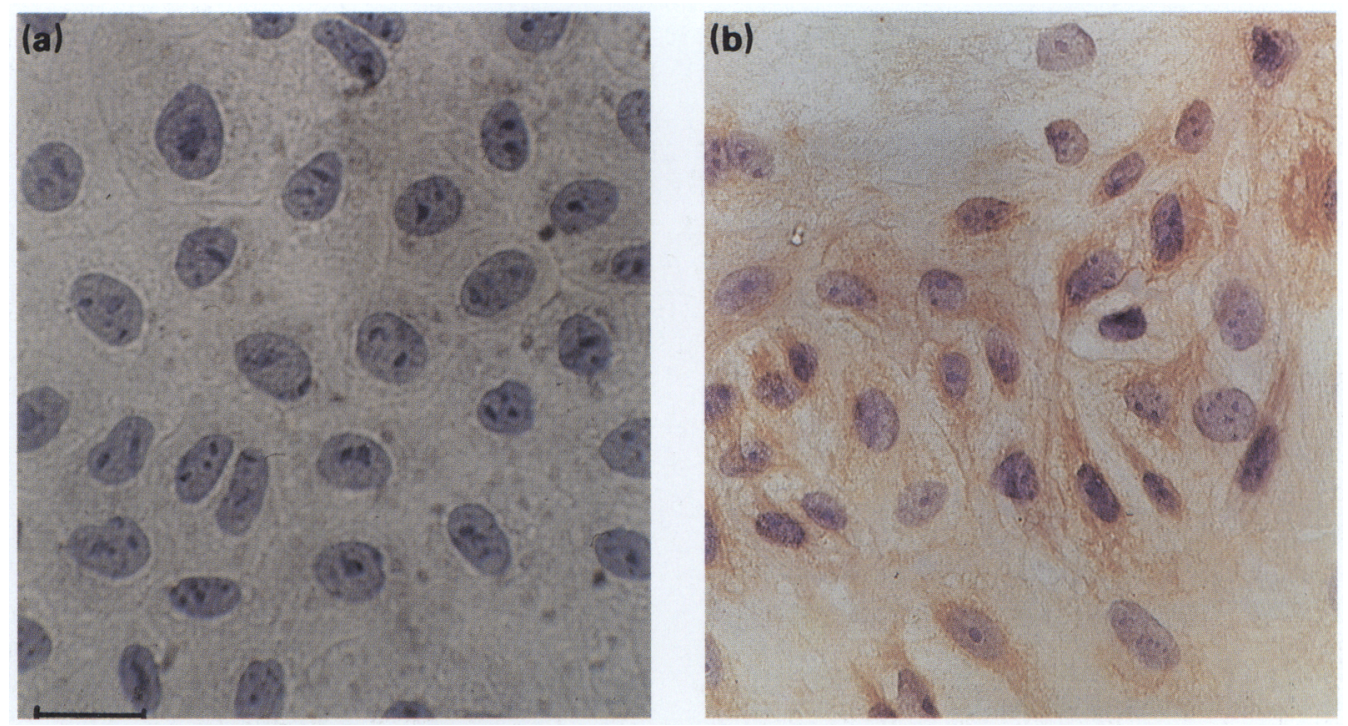

Fig. 1. Immunohistochemical characterization of cultured bovine oviduct epithelial cells. (a) Photomicrograph of cultured bovine oviduct epithelial cells (first passage) at subconfluency and stained with Harris-haematoxylin; (b) immunoperoxidase labelling of cultured bovine oviduct epithelial cells (first passage) with anti-cytokeratin monoclonal antibodies. Scale bar represents $10 \mu \mathrm{m}$.

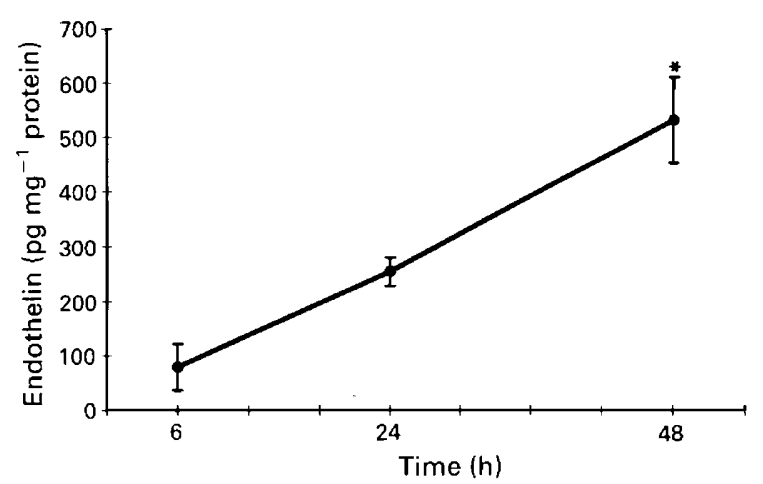

Fig. 2. Endothelin production by bovine oviduct epithelial cells in culture. Endothelin was assayed in the serum-free conditioned media after 6,24 and $48 \mathrm{~h}$ of incubation. ( $\left.{ }^{*}\right)$ Significant increase $(P<0.001)$ of endothelin production was observed after $48 \mathrm{~h}$ of incubation compared with after $6 \mathrm{~h}$ of culture. Each point represents the mean \pm SEM for assays conducted in duplicate from at least three different cell preparations.

$16 \mathrm{pg} \mathrm{mg}^{-1}$ protein $(P<0.05)$, an increase of $55 \%$. No cytotoxicity was observed in cells incubated for $6 \mathrm{~h}$ with the calcium ionophore; however, incubation of cells for more than $6 \mathrm{~h}$ caused significant toxicity and loss of cell viability. The trypan blue viability test revealed that $>98 \%$ of the cells remained viable even after $48 \mathrm{~h}$ of incubation in serum-free media. The total protein content of the cells in culture did not show any significant change during the $48 \mathrm{~h}$ of incubation in serum free medium.

\section{Discussion}

Bovine oviduct epithelial cells in culture released immunoreactive endothelin. The presence of endothelin was evaluated by a radioimmunoassay, which shows crossreactivity with ET-I, ET-2 and big ET-1. The observation that $94 \%$ of the cells in culture crossreacted with anti-cytokeratin monoclonal antibodies, and that the morphology of the cells was similar to that of the epithelia implies that the cultured cells were of epithelial origin. Significant amounts of endothelin were detected in the conditioned medium of bovine oviduct epithelial cells after $48 \mathrm{~h}$ in culture, without any changes in the total protein content and number of cells. In subcultured cells, the release of endothelin could be stimulated by the calcium ionophore A23187 (Emori et al., 1989). This observation is in agreement with a previous report, in which treatment of cultured vascular endothelial cells by A23187 also induced endothelin production (Boulanger and Lüscher, 1990). These findings confirm that immunoreactive endothelin is produced by bovine oviduct epithelial cells.

The oviduct under cyclic endocrine control provides an optimal environment for fertilization and early embryonic development. Muscle contractions and ciliary movement contribute to the essential transport of gametes and embryos, but the mechanism whereby the oviduct operates as a conduit is not completely known (Sayegh et al., 1991). Autonomic innervation as well as locally released peptides appear to control the contractions of the oviduct at different levels. The observation that bovine oviduct epithelial cells in culture release endothelin suggests that endothelin could play a local paracrine role in the cyclic contraction or may even affect the ciliary motion of the oviduct. The presence of endothelin in the reproductive tract is now well documented. For example, in the endometrium, endothelin seems to play a role in menstruation (Economos et al., 1992); and in the uterus, the contraction in response to endothelin can be reduced by treating the uterine segments with progesterone (McGovern et al., 1992). These observations imply that the effects of endothelin could also be hormonally controlled. In the study reported here Downloaded from Bioscientifica.com at 04/26/2023 01:22:49PM 
endothelin was found to be present in the conditioned medium of bovine oviduct epithelial cells in vitro; further studies are in progress to define the physiological role of endothelin in the oviduct. We speculate that endothelin could play an important role in the transport of gametes and embryos either by acting on the muscle coat of the oviduct or by interacting with the gamete surface.

The authors thank T. Rossi for technical assistance and R. K. Dubey, West Virginia University, USA for helpful suggestions and collaboration.

\section{References}

Bongso A, Nj SC, Sathananthan H, Ng PL, Rauff M and Ratmann SS (1989) Establishment of human ampullary cell cultures Human Reproduction 4 486-494

Boulanger C and Lüscher TF (1990) Release of endothelin from the porcine aorta: inhibition by endothelium-derived nitric oxide Journal of Clinical Investigation 85 587-590

Casey ML, Byrd W and MacDonald PC (1992) Massive amounts of immunoreactive endothelin in human seminal fluid Journal of Clinical Endocrinology and Metabolism 74 223-225

Davenport AP, Ashby MJ, Easton P, Ella S, Bedfod J, Dickenson C, Nunez DJ, Capper SJ and Brown MJ (1990) A sensitive radioimmunoassay measuring endothelin-like immunoreactivity in human plasma: comparison of level in patients with essential hypertension and normotensive control subjects Clinical Science 78 261-264

Economos K, MacDonald PC and Casey ML (1992) Endothelin-1 gene expression and protein biosynthesis in human endometrium: potential modulator of endometrial blood flow journal of Clinical Endocrinology and Metabolism 74 14-19
Emori T, Hirata Y, Ohta K, Shichri M and Marumo F (1989) Secretory mechanism of immunoreactive endothelin in cultured bovine endothelial cells Biochemical and Biophysical Research Communications 160 93-100

Inoue A, Yanagisawa M, Kimura S, Kasuya T, Miyauchi T, Goto K and Masaki T (1989) The human endothelin family: three structurally and pharmacologically distinct isopeptides predicted by three separate genes Proceedings of the National Academy of Science, USA $862863-2867$

Jakoby WB and Pastan IH (1979) Cell culture Methods in Enzymology 58

Kenigsberg D, Island L and Jefferson P (1992) Editorial: Endothelin and reproduction? The Journal of Clinical Endocrinology and Metabolism 74 12-13

Komuro I, Kuihara H, Sugiyama T, Yoshizumi M, Takaku F and Yazaki Y (1989) Endothelin stimulates c-fos and c-myc expression and proliferation of vascular smooth muscle cells FEBS Letters 27 244-252

Kozuka M, Ito T, Hirose S, Takahashi K and Hagiwara H (1989) Endothelin induces two types of contractions of rat uterus: phasic contractions by way of voltage-depended calcium channels and developing contractions through a second type of calcium channel Biochemical and Biophysical Research Communication 159 317-323

Lowry OH, Rosenbrough NJ, Farr AL and Randall RJ (195I) Protein measurements with Folin phenol reagent Journal of Biological Chemistry 193 265-275

McGovern PG, Goldsmith LT, Schmidt CL, VonHagen S, Linden M and Weiss G (1992) Effect of endothelin and relaxin on rat uterine segment contractility Biology of Reproduction 46 680-685

Moll R, Franke WW, Schiller DL, Geiger B and Krepler R (1982) The catalog of human cytokeratin: patterns of expression in normal epithelia, tumor and cultured cells Cell 31 11-22

Sayegh R and Mastroianni LJ (1991) Recent advances in our understanding of tubal function Annals of the New York Academy of Sciences, New York, 626 266-275

Yanagisawa M, Kurihara H, Kimura S, Tomobe Y, Kobayashi M, Mitsui Y, Yazaki Y, Goto K and Masaki T (1988) A novel potent vasoconstrictor peptide produced by vascular endothelial cells Nature 332 411-415

Yeko TR and Handler A (1991) The effect of aging on tubal function and ectopic pregnancy Seminars in Reproductive Endocrinology 9 215-220 